\title{
Pozitif ve Negatif Ağızdan Ăğıa Pazarlamanın Marka Tercihi Üzerine Etkisi: Hazır Giyim Sektörüne Yönelik Bir Araştırma
}

\section{The Effect of Positive and Negative Word of Mouth Marketing on Brand Choice: A Research for the Clothing Industry}

Zehra Türk, ${ }^{\mathrm{a}, *}$

a Öğr. Gör. Dr., Muğla Sitkı Koçman Üniversitesi, Marmaris Turizm MYO, 48720, Muğla/Türkiye

ORCID: 0000-0002-0769-1620

\section{MAKALE BILLGİSI}

\section{Makale Geçmişi:}

Başvuru tarihi: 25 Eylül 2019

Düzeltme tarihi: 03 Aralık 2019

Kabul tarihi: 18 Aralık 2019

\section{Anahtar Kelimeler:}

Pozitif Ağızdan Ağıza Pazarlama,

Negatif Ağızdan Ağıza Pazarlama,

Marka Tercihi
ÖZ

Bu çalışmanın amacı, hazır giyim sektöründe faaliyet gösteren LC Waikiki ve DeFacto markalarını kullanan tüketicilerin marka tercihlerinde pozitif ve negatif ağızdan ağıza pazarlama faaliyetlerinin etkisini araştırmaktır. Bu amaçla Muğla ilinde bu markaları kullanan tüketicilere yönelik anket uygulaması gerçekleştirilmiştir. Anket uygulaması sonucu elde edilen veriler basit regresyon analizi ile test edilmiştir. Analiz sonucunda, LC Waikiki ürünü kullananların marka tercihinde pozitif ağızdan ağıza pazarlama faaliyetlerinin etkisi 0.522 oranında iken, DeFacto ürünü kullananlarda bu oran 0.729 'dur. LC Waikiki markasının tercihinde negatif ağıdan ağıza pazarlama faaliyetlerinin etkisi negatif yönde 0.359 iken, DeFacto markasının tercihinde bu oran negatif yönde 0.749 'dur. Sonuç olarak, DeFacto markasını tercih eden tüketicilerin ağızdan ağıza pazarlama faaliyetlerinden etkilenme oranları LC Waikiki tüketicilerine göre daha yüksektir.

\section{ARTICLE INFO}

Article history:

Received 25 September 2019

Received in revised form 03 December 2019

Accepted 18 December 2019

\section{Keywords:}

Positive Word of Mouth Marketing,

Negative Word of Mouth Marketing,

Brand Preference.

\begin{abstract}
A B S T R ACT
The aim of this study was to investigate the impact of positive and negative word of mouth marketing activities on brand preferences of consumers using LC Waikiki and DeFacto brands operating in the garment sector. For this purpose, a survey was conducted for consumers using these brands in Muğla. The data obtained from the survey application was tested with simple regression analysis. As a result of the analysis, the effect of positive word of mouth marketing activities on brand preference of those who use LC Waikiki product is 0.522 , while it is 0.729 for those using DeFacto product. While the effect of negative word-of-mouth marketing activities in the preference of LC Waikiki brand is 0.359 in the negative direction, this ratio is 0.749 in the negative direction in the preference of the DeFacto brand. As a result, consumers who prefer the DeFacto brand are more likely to be affected by word of mouth marketing than LC Waikiki consumers.
\end{abstract}

\section{Giriș}

Üretim teknolojilerinde yaşanan gelişmeler ile birlikte, tüketicilere satın almaları için sunulan ürün ve hizmetlerde de çeşitlilik ortaya çıkmıştır. Tüketiciler satın alma kararı verirken, markaların da etkisi altında kalabilmektedirler. Satın alacakları ürün tercihlerinde, marka imajı da etkili olmaktadır. Marka imajını belirleyen en önemli unsurlardan bir tanesi, ilgili markanın kullanıcılar tarafindan nasıl algılandığıdır. Tüketicilerin markaya yönelik algılarında, ürün ve hizmeti daha önce kullananların görüş ve değerlendirmeleri etkili olabilmektedir. İletişim teknolojilerinin gelişmesi ile birlikte tüketiciler, ürün ve hizmetleri daha önce kullanan kişilerin görüş ve önerilerine daha hızlı bir şekilde ulaşabilmekte, satın alma kararı verirken bu yorumları dikkate almaktadır.

Tüketicilerin kullandıkları ürün ve hizmetler ile ilgili gerek internet ortaminda, gerekse sosyal ve yazılı medya

\footnotetext{
* Sorumlu yazar/Corresponding author.

e-posta: zehraturk@mu.edu.tr
} 
aracılığıyla görüş ve önerilerini paylaşmaları ağızdan ağıza pazarlama faaliyeti olarak görülmektedir. Ürün ve hizmeti kullananların olumlu yönde görüşlerini paylaşmaları pozitif ağızdan ağıza pazarlama, olumsuz görüşlerini paylaşmaları ise negatif ağızdan ağıza pazarlama olarak değerlendirilmektedir.

Hazır giyim sektöründe piyasada birçok marka bulunmaktadır. Tüketiciler hazır giyim sektöründe marka ile ilgili tercihlerini yaparken, markanın kullanıcıları tarafindan nasıl algılandığı önem arz etmektedir. Hakkında olumlu değerlendirmelerin yani pozitif ağıdan ağıza pazarlama faaliyetleri fazla olan ürünlerin piyasada tutunması ve satışlarının fazla olması kaçınılmaz bir durumdur. Aksi takdirde, hakkında olumsuz görüş ve önerilerin yaygın olduğu yani negatif ağızdan ağıza pazarlama faaliyetlerinin fazla olduğu markaların diğer markalar ile rekabet edebilmesi mümkün değildir.

İşletmeler, gelişen iletişim teknolojileri ile birlikte yaygınlaşan ağızdan ağıza pazarlama faaliyetlerini son dönemlerde daha çok önemsemeye başlamışlardır. Bu amaçla pazarlama departmanlarında ayrı bir bölüm oluşturarak ağızdan ağıza pazarlama faaliyetlerini kontrol eden, markaları ile ilgili olumsuz imaj oluşturabilecek kullanıcı şikâyetlerini dikkate alan ve bu şikâyetleri gidermeye çalışan ekipler oluşturmaya başlamışlardır.

Pozitif ve negatif yönde ağızdan ağıza pazarlama faaliyetlerinin tüketicilerin marka tercihleri üzerindeki etkisini belirlemeyi amaçlayan bu çalışmada, hazır giyim sektöründe faaliyet gösteren LC Waikiki ve DeFacto markalı ürünleri kullanan tüketicilerin görüşlerine yer verilmektedir. $\mathrm{Bu}$ amaçla Muğla ilinde bu markalı ürünleri kullanan tüketicilere yönelik alan araştırması gerçekleştirilmiş, elde edilen bulgular istatistiksel yöntemlerle analiz edilerek aktarılmaya çalışılmıştır.

\section{Kavramsal Çerçeve}

\subsection{Ağıdan Ağıza Pazarlama Kavramı}

Ağızdan ağıza pazarlama, viral pazarlama ya da söylenti pazarlaması (buzz marketing) olarak da adlandırılmaktadır (Arora, 2007: 51). Ağızdan pazarlama, müşterilerin alışveriş sonrasında satın aldıkları ürün ya da hizmetler ile ilgili görüşlerini firmadan bağımsız bir şekilde insanlara pozitif ya da negatif olarak aktarması şeklinde tanımlanmaktadır (Silverman, 2007: 43). Dick ve Basu (1994: 107) ağıdan ağıza pazarlamayı, müşterilerin kendi istekleri ile satın aldıkları ürünler hakkında başkaları ile iletişim kurmaları; memnuniyeti veya şikâyetlerini başkaları ile paylaşması şeklinde tanımlamaktadır. Richins (1983: 69)' e göre ağızdan ağıza pazarlama, tüketicilerin bir örgüt, ürün veya hizmete dair kullanım deneyimlerini kendi aralarında gönüllü bir şekilde paylaşmalarıdır. Bu bilgi alışverişi örgütler için kendi avantajlarına kullanabilecekleri önemli bir bilgi kaynağıdır. Litvin vd., (2006: 461) ise ağızdan ağıza pazarlama iletişimini, herhangi bir ticari kimliği bulunmayan kişilerin ürün veya işletme ile ilgili deneyimlerini yüz yüze görüşme şeklinde ifade etme süreci olarak değerlendirmektedir.

Ağızdan ağıza pazarlama, kişi yada grupların hizmetler ve örgütler hakkında ortaya koydukları iki yönlü iletişim türü şeklinde de değerlendirilmektedir. Sıfır medya olarak nitelendirilen bu iletişim türünde bilginin karşı tarafa aktarım maliyeti sıfira inebilmektedir. Modern iletişim teknolojilerinin gelişmesi ve internetin yaygınlaşması ile birlikte ağızdan ağıza pazarlama modern işletmeler için güçlü bir etkiye yol açmıştır. İnternet ile birlikte beklenmedik bir şekilde yoğunlaşan ağızdan ağıza pazarlama anlayışı, işletmelerin bu duruma hazırlıksız yakalanmalarına neden olmuştur (Güven, 2014: 52).

Ürün ve hizmetlere yönelik bilgi yayılımı iki şekilde gerçekleşmektedir. Bunlar organik yayılma ve geleneksel yayilmadır (Carl, 2006: 623). Marka ile ilgili online ya da yüz yüze çeşitli ortamlarda konuşan kişilerin ilgili kuruluşla herhangi bir bağının olmaması, tamamen bağımsız bir şekilde görüşlerin paylaşıldığı bilgi yayılım türü organik yayılım olarak değerlendirilmektedir. Organik yayılmada kişilerin kendi istekleri ile memnuniyet ve memnuniyetsizliklerini başkaları ile paylaşması söz konusudur. Geleneksel yayılmada ise, önceden planlanmış ağızdan ağıza pazarlama kampanyası söz konusudur. Geleneksel yayılmada, sosyal gruplar oluşturmak bireylerin fikirlerini paylaşabilecekleri ortamlar geliştirmek; marka elçileri bulmak ve onları paylaşabilecekleri bilgiler konusunda desteklemek; çevrimiçi sohbet sitelerini takip etmek ve topluluklar içerisinde ağızdan ağıza pazarlama faaliyetlerini yaygınlaştırmak amacıyla gerçekleştirilen uygulamalar sayılabilir (Carl, 2006: 624). Avon, Oriflame, Amway, Herbal Life, Tupperware gibi işletmelerin uyguladıkları ağızdan ağıza pazarlama faaliyetlerini geleneksel yayılıma örnek vermek mümkündür. $\mathrm{Bu}$ markaların kullanıcıları aynı zamanda satış temsilcileri gibi hareket etmekte ve yakın çevrelerini ürünler ile ilgili bilgilendirmektedirler (Güven, 2014: 54)

Ağızdan ağıza pazarlamanın üç yöntemi bulunmaktadır. Bunlar viral pazarlama, elektronik ağızdan ağıza pazarlama ve fisıltı yoluyla (buzz) pazarlamadır (Bayındır, 2019: 3841).

Viral pazarlama: Ağızdan ağıza pazarlamanın gelişmiş bir şeklidir. Viral pazarlamada tüketiciler, ürün ve hizmet ile ilgili beğenilerini e-mail veya sosyal medya aracılığıyla paylaşma eğilimindedir (Dafonte-Gómez, 2013: 204). İnternet sitesi ve görsel materyaller aracılığıyla; tüketicilerde paylaşılmaya değecek şekilde mesaj oluşturma, ürün ya da firma lehine gizli mesajların geniş kitlelere yayılmasını sağlamaya, viral pazarlama denilmektedir (Sim ve Toprak, 2012: 4).

Elektronik ă̆ızdan ăgıza pazarlama: Bilgi teknolojileri ve internetin gelişimi ile birlikte ağızdan ağıza pazarlama anlayışı elektronik ortama taşınmıştır (Thorson ve Rodgers, 2006: 40; Dellarocas, 2003: 1407). Hennig-Thurau vd. (2004: 39)'ne göre elektronik ağızdan ağıza pazarlama, mevcut müşteriler ve müşteri olma potansiyeli olan kullanıcıların internetteki insan grupları ile yaptıkları olumlu veya olumsuz yorumlardır. Elektronik ağızdan ağıza pazarlamada sosyal ağlar, forumlar ve internet üzerindeki bloglar kullanılmaktadır (Bayındır, 2019: 41).

Fısıltı yoluyla (Buzz) pazarlama: Bu pazarlama türünde ürün ve hizmetleri tecrübe eden tüketicilerin diğer müşteriler ile bir araya gelip deneyimlerini paylaştıkları konuşmaların yer aldığı ortamlar söz konusudur (Kahn ve Wind, 2005: 2). Fısıltı yolu ile ağızdan ağıza pazarlamada tüketiciler mesaj yaymakta zorlanmazlar ve iletilmek istenen mesajları doğal bir şekilde gerçekleştirdikleri için daha etkilidir (Thomas, 
2004: 66). Bu pazarlama türünde müşterilerin ve medya organlarının dikkatlerini çekmek ve markaya odaklanmalarını sağlamak amacıyla dikkat çekici, heyecan verici ve akılda kalıcı mesajlar ağızdan ağıza paylaşılmaya çalışılır (Mohr, 2007: 396).

\subsection{Marka Tercihi}

Marka, satıcıların pazara sundukları ürünlerde kimlik oluşturmak için tasarladıkları, diğer ürünlerden farklılaşmasını sağlayan isim, işaret, sembol ya da tasarım olarak tanımlanmaktadır (Kotler ve Armstrong, 2006: 243). Marka tercihi, tüketicilerin satın aldıkları ürün ve hizmetten duydukları memnuniyet sonucunda satın alma faaliyetine devam etmesi marka tercihi olarak değerlendirilmektedir (Loudon ve Bitta, 1993: 31). Punj ve Hillyer (2004: 126) marka tercihini, satın alma faaliyeti gerçekleşmeden önce aynı ürün veya hizmet kolunda rekabet eden markalar arasından bir tanesini seçmesi olarak tanımlamaktadır. Tüketicilerin ihtiyaçları ile gerçekleşen satın alma arzusu ve markaya ilişkin duygu ve düşüncelerin etkisi ile bir markanın seçilmesi süreci tüketicilerin marka tercihini ifade etmektedir (Aktuğlu, 2004: 36).

Tüketicilerin marka tercihini etkileyen en önemli unsurlardan bir tanesi marka imajıdır. Marka imajı, tüketicilerin marka ile ilgili duyumları, deneyimleri, reklamlar ile elde edilen bilgiler çerçevesinde oluşan alg1 olarak tanımlanmaktadır. Marka tercihi, tüketicilerin ihtiyaçları ve beklentileri ile markaya karşı oluşan duygu ve düşüncelerin toplamı neticesinde satın alma kararını verirken bir markayı seçmeleri olarak tanımlanmaktadır (Aktuğlu ve Temel 2006: 44).

\subsection{Literatür Taraması ve Araştırmanın Hipotezleri}

Literatürde ağızdan ağıza pazarlamaya yönelik çalışmalar incelendiğinde birçok çalışmanın yer aldığı görülmektedir. Goyette vd., (2010) tarafindan ağızdan ağıza pazarlamanın etkisine yönelik yapılan araştırmada, ağızdan ağıza pazarlamanın gazetede çıkan haberlerden sekiz kat, doğrudan satışa yönelik yapılan aktivitelerden dört kat, radyoda yayınlanan reklamlardan iki kat daha fazla etkili olduğu sonucuna ulaşılmıştır. Trusov vd., (2009) tarafindan yapılan benzer bir araştırmada ise, ağızdan ağıza pazarlamanın gazete ve dergi yayınlarından yedi kat, kişisel satışa yönelik yapılan faaliyetlerden dört kat, radyo reklamlarından ise iki kat daha etkili olduğu görülmüştür. Chia-Hung (2008) yaptığı araştırmada ağızdan ağıza pazarlamanın olumlu olduğunda tüketicilerin aynı markayı satın alma eğilimlerinin yüksek olduğunu belirtmiştir. Silverman (2007) ve Alexandris vd. (2007) çalışmalarında, ağızdan ağıza iletişimin etkisini araştırmışlar, tüketim deneyimleri sonucunda ürün veya hizmetin faydalarının yayılmasının müşterilerin satın alma tercihinde etkili olduğu sonucuna ulaşmışlardır. Marangoz (2007) cep telefonu kullanıcılarına yönelik yaptığı araştırmada, ağızdan ağıza iletişimin müşterilerin tekrarlı satın alma faaliyetlerinde etkili olduğunu belirtmiştir. Murray (1991) tarafindan yapılan araştırmada, tüketicilerin satın aldıkları ürün ve hizmete ilişskin karşılaşacakları riski en aza indirmek adına ağızdan ağıza pazarlamadan yararlandıkları belirtilmiş; hizmet alımlarında ürün alımına göre daha fazla risk algısı olduğu sonucuna ulaşılmıştır. Hahn vd. (1994) tarafindan yapılan araştırmada, mamul yaşam eğrisinde ağızdan ağıza pazarlamanın ilk aşamada daha etkili olduğu, ürün özelliklerinin yayılmasında ve pazar rekabeti açısından ağızdan ağıza pazarlamanın etkili olduğu sonucuna ulaşmışlardır. Godes ve Mayzlin (2004) ağızdan ağıza pazarlamayı büyüklük ve yayılma açısından incelemişlerdir. Araştırmalarında, internet üzerinden yapılan çevrimiçi sohbet gruplarındaki ağızdan ağıza pazarlamanın yayılım açısından daha etkili olduğunu tespit etmişlerdir. Iacobucci ve Hopkins (1992) ağızdan ağıza pazarlamanın yayılım hızına yönelik yaptıkları araştırmada, yayılım hızının kişisel olmayan ürünlere göre daha yavaş olduğu sonucuna ulaşmışlardır.

Marka tercihi ile ilgili literatürde hem ulusal hem uluslararası birçok araştırma yer almaktadır. Heilman vd.,(2000) tarafından yapılan araştırmada tüketiciler, risk algısını en aza indirmek için marka tercihinde marka imajına dikkat ettiklerini belirtmişlerdir. Torlak ve Özmen, (2006) tarafından yapılan çalışmada da marka tercihi belirleyicileri arasında marka imajının etkili olduğu sonucuna ulaşılmıştır. Pickett-Baker ve Ozaki (2008) tarafindan yapilan araştırmada ise, tüketicilerin marka tercihlerinde çevreye olan duyarlılıkları araştırılmış; kullanıcıların çevre dostu markaları tercih ettikleri ve bunun için diğerlerine nazaran daha yüksek ödeme yapmayı göze aldıkları ortaya konmuştur. Kardeş (2011) ise Türk tüketicilerin marka tercihlerinde çevre dostu uygulamaların etkisini araştırmış ve çevreci kişiliğin marka tercihi üzerinde etkili olduğunu tespit etmiştir. Nan (2009) tarafından yapılan araştırmada ise, marka tercihi üzerinde işletmelerin faaliyetlerinin inandırıcılığının etkili olduğu belirtilmektedir. Marka tercihini etkileyen unsurlar arasında kültürel değerlerin de etkisinin azımsanmayacak düzeyde olduğu yapılan araştırmalarda ortaya konmuştur (Lim ve O'Cass, 2001; Overby vd., 2004; Goldberg ve Baumgartner, 2002). Lüks ürünlerde marka tercihi yapılırken, üretilen ülkenin gelişmişlik düzeyinin marka tercihi üzerinde etkili olduğu tespit edilmiştir (Piron, 2000; Varinli ve Babayiğit, 2000).

Yıldız (2014) tarafından, ağızdan ağıza pazarlama ile tüketici temelli marka değeri arasındaki ilişkide marka tercihi aracılık rolü açısından incelenmiş, araştırma sonucunda marka tercihinin kısmen aracılık rolü olduğu belirlenmiştir.

Yıldız (2015a) tarafından Ankara'da mobil telefon kullanıcılarına yönelik yapılan bir araştırmada, ağızdan ağıza pazarlamanın marka tercihi üzerindeki etkileri araştırılmıştır. Araştırma neticesinde ağızdan ağıza pazarlamanın marka tercihini 0.21 oranında etkilediği tespit edilmiştir.

Üniversite öğrencilerinin marka tercihlerinde ağızdan ağıza pazarlamanın etkisine yönelik Yıldız (2015b) tarafindan yapılan araştırmada, ağızdan ağıza pazarlamanın öğrencilerin marka tercihlerinde 0.74 oranında etkili olduğu sonucuna ulaşılmıştır.

Literatürde yer alan çalışmalar 1şı̆̆ında araştırmanın amacına uygun olarak aşağıdaki hipotezler geliştirilmiştir.

Hipotez 1: Pozitif ă̆ızdan ă̆ıza pazarlama çabaları, tüketicilerin LC Waikiki marka tercihinde pozitif yönde etkilidir.

Hipotez 2: Negatif Ă̆ızdan ă̆ıza pazarlama çabaları tüketicilerin LC Waikiki marka tercihinde negatif yönde etkilidir. 
Hipotez 3: Pozitif ăgızdan ăğza pazarlama çabaları tüketicilerin DeFacto marka tercihinde pozitif yönde etkilidir.

Hipotez 4: Negatif Ă̆ıddan ă̆ıza pazarlama çabaları tüketicilerin DeFacto marka tercihinde negatif yönde etkilidir.

\section{Metodoloji}

\subsection{Amaç ve Yöntem}

$\mathrm{Bu}$ çalışmanın amacı hazır giyim sektöründe faaliyet gösteren LC Waikiki ve De Facto giyim markalarını kullanan tüketicilerin, marka tercihlerinde pozitif ve negatif ağızdan ağıza pazarlamanın etkisini ortaya koymaktır. Araştırmanın amacına yönelik olarak LC Waikiki ve De Facto müşterilerine yönelik anket uygulaması gerçekleştirilmiştir. Anket uygulaması Mayıs-Haziran 2019 tarihleri arasında tüketicilerle yüz yüze görüşme şeklinde gerçekleştirilmiştir. Anket uygulaması neticesinde elde edilen bulgular betimsel istatistik ve basit doğrusal regresyon analizi ile test edilmiş ve sonuçları tablolar halinde aktarılmaya çalışılmıştır.

\section{2. Örneklem ve Veri Toplama Aracı}

Araştırma Muğla ilinde gerçekleştirilmiştir. Araştırmanın evrenini Muğla ilinde hem LC Waikiki hem de De Facto ürünlerini daha önce satın almış ve kullanmış müşteriler oluşturmaktadır. Araştırma evreninin 10.000 'den fazla olduğu durumlarda evreni temsil edecek örneklem sayısının en az 384 olması gerekmektedir (Sekaran, 1992: 253). Araştırmaya 525 müşteri katılmıştır. Araştırmada elde edilen anket verileri IBM SPSS 25. 0 programı aracılığıly analize tabi tutulmuştur.

Araştırmada kullanılan anket formunun oluşturulmasında kullanılan ölçeklere ilişkin bilgiler şu şekildedir:

Ağızdan Ağıza Pazarlama Ölçeği: Ölçekte pozitif ağızdan ağıza pazarlama ile ilgili beş ifade, negatif ağızdan ağıza pazarlama ile ilgili de beş ifade olmak üzere toplam on ifade yer almaktadır. Pozitif ağızdan ağıza pazarlamaya yönelik ifadeler bir boyutta, negatif ağızdan ağıza pazarlamaya yönelik ifadeler bir boyutta olmak üzere ağızdan ağıza pazarlama ölçeği iki boyut olarak analizlere tabi tutulmuştur. Ölçeğin orijinali Godes ve Mayzlin (2004) tarafindan hazırlanmış, Yıldız (2014) tarafından Türkçe' ye uyarlanarak geçerlilik ve güvenilirlik analizleri gerçekleştirilmiştir.

Marka Tercihi Ölçeği: Ölçek kullanıcıların marka tercihlerine yönelik beş ifadeden oluşmaktadır. Ölçeğin orijinalinde de olduğu gibi tek boyut olarak değerlendirmeye tabi tutulmuştur. Ölçeğin orijinali Chang ve Liu (2009) tarafından oluşturulmuş, Yıldız (2014) tarafından Türkçe' ye uyarlanmıştır.

Ağızdan ağıza pazarlama ölçeği ve marka tercihi ölçeğindeki yanıtlar beşli likert ölçeğine göre cevaplanmıştır. İfadelerin puanlanmasında 1- Kesinlikle Katılmıyorum, 5-Kesinlikle Katılıyorum şeklinde değerlendirilmiştir.

\subsection{Verilerin Analizi ve Bulgular}

Araştırmada elde edilen verilerin analizi ve hipotezlerin değerlendirilmesi \%95 güven aralığı dikkate alınarak yapilmıştır.

\subsubsection{Demografik Bulgular}

Araştırmaya LC Waikiki ve DeFacto hazır giyim markalarını kullanan 525 tüketici katılmıştır. Tüketicilerin yaş dağılımları incelendiğinde; 69 (\%13. 1)' u 20 yaş altında, 213 (\%40. 6)' ü 20 ile 29 yaş aralığında, 126 (\%24. 0)' s1 30 ile 39 yaş aralığında, $102(\% 19.4)$ ' si 40 ile 49 yaş aralığında ve $15(\% 2$. 9)' i 50 yaş ve üzerindeki kişilerden oluşmaktadır. Katılımcıların cinsiyete göre dağılımlarına bakıldığında ise; 321 (\%61. 1)' i kadın, 204 (\%38. 9)' ü erkek tüketicilerden oluşmaktadır. Eğitim düzeyleri incelendiğinde; 21 (\% 4. 0)'i ilköğretim mezunu, 72 (\%13. 7)' si lise, $276(\% 52.6)$ si önlisans ve $156(\% 29.7)$ ' s1 lisans mezunu oldukları tespit edilmiştir. Araştırmaya katılan tüketicilerin medeni durumlarına göre dağılımı ise; 282 (\%53. 7) kişinin evli, 243 (\%46.3) kişinin bekâr olduğu belirlenmiştir.

\subsubsection{Güvenilirlik Analizi ve Tanımlayıcı Bulgular}

Araştırma sonucu elde edilen verilerin güvenilirlik analizi gerçekleştirildiğinde; pozitif ağızdan ağıza pazarlamaya yönelik ifadelerin güvenilirlik değeri 0 . 778; negatif ağıdan ağıza pazarlamaya yönelik ifadelerin güvenilirlik değeri ise 0.747 'dir. Tüketicilerin marka tercihine yönelik ifadelerin güvenilirlik değeri 0.744 'dür. Kalaycı (2008)' e göre alpha değeri 0.60 ile 0.80 aralığında ise ölçek oldukça güvenilirdir. Güvenilirlik analizi sonucuna göre araştırmada kullanılan ölçeklerin oldukça güvenilir oldukları anlaşılmaktadır.

Tablo 1: Ölçeklere İlişkin Betimsel İstatistik Tablosu

\begin{tabular}{|c|c|c|c|c|}
\hline Marka & Ölçekler & $\mathbf{N}$ & Ort. & S.S. \\
\hline \multirow{3}{*}{$=$} & $\begin{array}{l}\text { Pozitif Ağızdan Ağıza } \\
\text { Pazarlama }\end{array}$ & 525 & 2.71 & .968 \\
\hline & $\begin{array}{l}\text { Negatif Ağızdan Ağıza } \\
\text { Pazarlama }\end{array}$ & 525 & 3.49 & .922 \\
\hline & Marka Tercihi & 525 & 2.77 & .961 \\
\hline \multirow{3}{*}{ 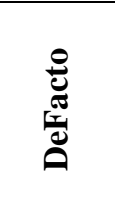 } & $\begin{array}{l}\text { Pozitif Ağızdan Ağıza } \\
\text { Pazarlama }\end{array}$ & 525 & 3.03 & .993 \\
\hline & $\begin{array}{l}\text { Negatif Ağızdan Ağıza } \\
\text { Pazarlama }\end{array}$ & 525 & 2.93 & .877 \\
\hline & Marka Tercihi & 525 & 2.96 & .923 \\
\hline
\end{tabular}

Tablo 1' de yer alan betimsel istatistik sonuçları incelendiğinde, hazır giyim markalarından LC Waikiki ile DeFacto markalarını kullanan tüketicilerin pozitif ağızdan ağıza pazarlama faaliyetleri gerçekleştirdikleri görülmektedir. DeFacto markasına yönelik pozitif ağızdan ağıza pazarlamanın ortalama değeri LC Waikiki markasına göre daha yüksektir. Negatif ağıdan ağıza faaliyetleri açısından değerlendirme yapıldığında ise, LC Waikiki markasına yönelik negatif ağızdan ağıza pazarlamanın DeFacto markasına göre daha fazla olduğu görülmektedir. Araştırmaya katılan tüketicilerin marka tercihlerine yönelik ortalama değerlerinde ise DeFacto markasının LC Waikiki markasına göre daha yüksek oranda tercih edildiği görülmektedir. 


\subsubsection{Hipotezlerin Analizi}

Araştırmaya yönelik olarak geliştirilen hipotezlerin analizinde basit doğrusal regresyon analizi kullanılmıştır. Analiz sonuçları \%95 güven aralığına göre değerlendirilmiştir. Aşağıda hipotezlere yönelik bulgular ve değerlendirmeler tablolar halinde sunulmaktadır.

Hipotez 1: Pozitif ă̆ızdan ăğza pazarlama çabaları, tüketicilerin LC Waikiki marka tercihinde pozitif yönde etkilidir.

Tablo 2: Hipotez 1: Basit Doğrusal Regresyon Analizi Tablosu

\begin{tabular}{|c|c|c|c|c|c|}
\hline Bağımlı De & ken: & Iarka Terci & i (LC & Vaikiki) & \\
\hline $\begin{array}{l}\text { Bağımsız } \\
\text { Değişken }\end{array}$ & $\mathbf{R}^{2}$ & $\mathbf{F}$ & $\beta$ & $\mathbf{t}$ & $\mathbf{p}$ \\
\hline $\begin{array}{l}\text { Pozitif } \\
\text { Ağıdan } \\
\text { Ağıza } \\
\text { pazarlama } \\
\text { (LC } \\
\text { Waikiki) }\end{array}$ & .276 & $199.237^{* *}$ & .522 & 14.115 & $.000^{* *}$ \\
\hline
\end{tabular}

$* p<0,05 * * p<0,01$

Tablo 2' de yer alan, LC Waikiki kullanıcılarına yönelik, pozitif ağızdan ağıza pazarlama faaliyetlerinin marka tercihine olan etkisini belirlemek amacıyla gerçekleştirilen basit doğrusal regresyon analizi modelinde istatistiksel olarak anlamlı sonuçlar elde edilmiştir. LC Waikiki kullanıcılarının marka tercihlerinin pozitif ağızdan ağıza pazarlama faaliyetleri ile açıklanma oranı $\left(\mathrm{R}^{2}\right)$ 0.276'dır. Regresyon modelinde Beta değeri incelendiğinde 0.522 olduğu görülmektedir. Lc Waikiki kullanıcıları için pozitif ağızdan ağıza pazarlama faaliyetlerinin marka tercihlerini pozitif yönde etkiledikleri tespit edilmiş ve Hipotez 1 kabul edilmiştir.

Hipotez 2: Negatif Ă̆ıddan ă̆ıza pazarlama çabaları tüketicilerin LC Waikiki marka tercihinde negatif yönde etkilidir.

Tablo 3: Hipotez 2: Basit Doğrusal Regresyon Analizi Tablosu

Bağımlı Değişken: Marka Tercihi (LC Waikiki)

\begin{tabular}{lllllll}
\hline $\begin{array}{l}\text { Bağımsız } \\
\text { Değişken }\end{array}$ & $\mathbf{R}^{2}$ & $\mathbf{F}$ & $\boldsymbol{\beta}$ & $\mathbf{t}$ & $\mathbf{p}$ \\
\hline
\end{tabular}

$\begin{array}{llllll}\text { Negatif } & & & & & \\ \text { Ağ1zdan } & & & & & \\ \text { Ağ1za } & & & & & \\ \text { pazarlama } & .119 & 70.499^{* *} & -.359 & -8.396 & .000^{* *} \\ \text { (LC } & & & & & \\ \text { Waikiki) } & & & & & \\ *_{p}<0,05 * * p<0,01 & & & & \\ \end{array}$

Tablo 3'te yer alan, LC Waikiki kullanıcılarına yönelik olarak, negatif ağızdan ağıza pazarlama faaliyetlerinin marka tercihleri üzerindeki etkisini belirlemek amaciyla gerçekleştirilen basit doğrusal regresyon analizinde istatistiksel olarak anlamlı sonuçlar elde edilmiştir. LC
Waikiki kullanıcılarının marka tercihlerinin negatif ağızdan ağıza pazarlama faaliyetleri ile açıklanma oranı $\left(\mathrm{R}^{2}\right)$ 0.119 'dur. Negatif ağızdan ağıza pazarlama faaliyetleri marka tercihini negatif yönde etkilemektedir. Beta değeri incelendiğinde negatif ağızdan ağıza pazarlamanın marka tercihine etkisi negatif yönde 0.359 'dur. Hipotez 2 kabul edilmiştir.

Hipotez 3: Pozitif ă̆ızdan ă̆ıza pazarlama çabaları tüketicilerin DeFacto marka tercihinde pozitif yönde etkilidir.

Tablo 4: Hipotez 3: Basit Doğrusal Regresyon Analizi Tablosu

Bağımlı Değişken: Marka Tercihi (DeFacto)

\begin{tabular}{|c|c|c|c|c|c|}
\hline $\begin{array}{l}\text { Bağımsız } \\
\text { Değișken }\end{array}$ & $\mathbf{R}^{2}$ & $\mathbf{F}$ & $\beta$ & $\mathbf{t}$ & $\mathbf{p}$ \\
\hline $\begin{array}{l}\text { Pozitif } \\
\text { Ağıdan } \\
\text { Ağ1za } \\
\text { pazarlama } \\
\text { (DeFacto) }\end{array}$ & .663 & $1027.459^{* *}$ & .729 & 32.054 & $.000^{* *}$ \\
\hline
\end{tabular}

$* p<0.05 * * p<0.01$

Tablo 4'te yer alan, hazır giyim markası DeFacto kullanıcılarına yönelik, pozitif ağızdan ağıza pazarlama faaliyetlerinin marka tercihine olan etkisini belirlemek amaciyla gerçekleştirilen basit doğrusal regresyon analizi modelinde istatistiksel olarak anlamlı sonuçlar elde edilmiştir. DeFacto kullanıcılarının marka tercihlerinin pozitif ağızdan ağıza pazarlama faaliyetleri ile açıklanma oranı ( $\left.\mathrm{R}^{2}\right)$ 0.663'dür. Regresyon modelinde Beta değeri incelendiğinde 0.729 olduğu görülmektedir. DeFacto markası kullanıcıları için pozitif ağızdan ağıza pazarlama faaliyetlerinin marka tercihlerini pozitif yönde etkiledikleri sonucuna ulaşılmış ve Hipotez 3 kabul edilmiştir.

Hipotez 4: Negatif Ă̆ızdan ă̆ıza pazarlama çabaları tüketicilerin DeFacto marka tercihinde negatif yönde etkilidir.

Tablo 5: Hipotez 4: Basit Doğrusal Regresyon Analizi Tablosu

Bağımlı Değişken: Marka Tercihi (DeFacto)

\begin{tabular}{lccccc}
\hline $\begin{array}{l}\text { Bağımsız } \\
\text { Değişken }\end{array}$ & $\mathbf{R}^{2}$ & $\mathbf{F}$ & $\boldsymbol{\beta}$ & $\mathbf{t}$ & $\mathbf{p}$ \\
\hline $\begin{array}{l}\text { Negatif } \\
\text { Ağızdan }\end{array}$ & & & & & \\
$\begin{array}{l}\text { Ağıza } \\
\text { pazarlama } \\
\text { (DeFacto) }\end{array}$ & .508 & $539.764^{* *}$ & -.749 & -23.233 & $.000^{* *}$ \\
\hline$*_{p<0,05 * * p<0,01}$ & & & & \\
\hline
\end{tabular}

DeFacto marka ürün kullanıcılarına yönelik, negatif ağızdan ağıza pazarlama faaliyetlerinin marka tercihleri üzerindeki etkisini belirlemek amacıyla gerçekleştirilen basit doğrusal regresyon analizinde istatistiksel olarak anlamlı sonuçlar elde edilmiştir. DeFacto kullanıcılarının marka tercihlerinin negatif ağızdan ağıza pazarlama faaliyetleri ile açıklanma oranı $\left(R^{2}\right) 0.508^{\prime}$ dir. Negatif ağızdan ağıza pazarlama 
faaliyetleri marka tercihini negatif yönde etkilemektedir. Beta değeri incelendiğinde negatif ağızdan ağıza pazarlamanın DeFacto marka tercihine etkisi negatif yönde 0.749'dur. Hipotez 4 kabul edilmiştir.

\section{Değerlendirme ve Sonuç}

Hazır giyim sektöründe faaliyet gösteren LC Waikiki ve DeFacto markalarını kullanan tüketicilerin, marka tercihlerinde, pozitif ve negatif ağızdan ağıza pazarlama faaliyetlerinin etkisini araştıran bu çalışmada istatistiksel olarak anlamlı sonuçlar elde edilmiştir. Araştırmaya katılan tüketicilerin pozitif ağızdan ağıza pazarlama faaliyetlerine yönelik betimsel istatistik analizleri incelendiğinde, DeFacto markasının LC Waikiki' ye göre ortalama değerinin daha yüksek olduğu görülmektedir. Negatif ağızdan ağıza pazarlama faaliyetlerine ilişkin ortalama değerde LC Waikiki markasının DeFacto markasına göre daha yüksek olduğu tespit edilmiştir. Araştırmaya katılan tüketicilerin marka tercihi ortalamaları incelendiğinde ise, DeFacto markasını tercih etme oranı daha yüksektir. LC Waikiki markası kullanan tüketicilerin, pozitif ağızdan ağıza pazarlama faaliyetlerinin marka tercihleri üzerindeki etkisini belirlemek amaciyla gerçekleştirilen regresyon analizi neticesinde pozitif yönlü ve 0.522 oranında bir etki olduğu belirlenmiştir. DeFacto markasını kullanan tüketicilerde ise pozitif ağızdan ağıza pazarlama faaliyetlerinin etkisi 0.729 oranındadır. Araştırma sonucuna göre, DeFacto markasını kullanan tüketiciler LC Waikiki kullanıcılarından daha yüksek oranda pozitif ağızdan ağıza pazarlama faaliyetlerinden etkilenmektedir. Yildiz (2015a) tarafindan mobil telefon kullanıcılarına yönelik olarak yapılan benzer bir araştırmada, ağızdan ağıza pazarlama faaliyetlerinin marka tercihi üzerinde 0.21 oranında etkisi olduğu belirlenmiştir. Yine Yıldız (2015b) tarafından üniversite öğrencilerinin marka tercihlerine yönelik yapılan başka bir araştırmada ise, ağızdan ağıza pazarlama faaliyetlerinin üniversite öğrencilerinin marka tercihleri üzerindeki etkisinin 0.74 oranında olduğu tespit edilmiştir.

Negatif ağızdan ağıza pazarlamanın tüketicilerin marka tercihlerine yönelik etkilerini belirlemek için gerçekleştirilen regresyon analizi sonucunda da anlaml neticeler elde edilmiştir. LC Waikiki kullanıcılarının negatif ağızdan ağıza pazarlama faaliyetlerinin marka tercihlerindeki olumsuz etkisi 0.359 oranındadır. DeFacto kullanıcılarında negatif ağızdan ağıza pazarlama faaliyetlerinin etkisi ise olumsuz yönde ve 0.749 oranındadır. DeFacto markasının kullanıcıları LC Waikiki kullanıcılarına göre negatif ağızdan ağıza pazarlama faaliyetlerinden daha yüksek oranda etkilenmektedirler.

Sonuç olarak, araştırma neticesinde ağızdan ağıza pazarlama faaliyetlerinin tüketicilerin marka tercihlerinde etkili olduğu sonucuna ulaşılmıştır. Marka imajlarını korumak isteyen ve rekabet avantajı sağlamak isteyen firmaların ağızdan ağıza pazarlama çabalarına önem vermesi gerektiği sonucu ortaya çıkmaktadır. Bununla ilgili profesyonel ekipler kurarak, gerek internet ortamında gerekse yazılı ve görsel medya üzerinden markaları ile ilgili ağızdan ağıza pazarlama faaliyetlerini yönetmeleri ve bu algının olumlu yönde olması için çaba harcamaları gerekmektedir. Araştırmanın ortaya koyduğu sonuçlar itibariyle bilim camiasına da katkıda bulunacağı düşünülmektedir. Sonraki çalışmalara öneri olarak, farklı sektörler ve farklı markalar üzerindeki karşılaştırmalar ile araştırmanın genişletilmesi mümkündür.

\section{Kaynakça}

Aktuğlu, I. K. (2004). Marka yönetimi. İstanbul: İletişim Yayınları.

Aktuğlu, I. K., \& Temel, A. (2006). Tüketiciler markaları nasıl tercih ediyor?(Kamu sektörü çalışanlarının giysi markalarını tercihini etkileyen faktörlere yönelik bir araştırma). Selçuk Üniversitesi Sosyal Bilimler Enstitüsü Dergisi, (15), 43-59.

Alexandris, K., Tsaousi, E., \& James, J. (2007). Predicting sponsorship outcomes from attitudinal constructs: The case of a professional basketball event. Sport Marketing Quarterly, 16(3), 130-139.

Arora, H. (2007). Word of mouth in the world of marketing. The Icfai Journal of Marketing Management, 6(4), 51-65.

Carl, W. J. (2006). What's all the buzz about? Everyday communication and the relational basis of word-ofmouth and buzz marketing practices. Management Communication Quarterly, 19(4), 601-634.

Chang, H. H., \& Liu, Y. M. (2009). The impact of brand equity on brand preference and purchase intentions in the service industries. The Service Industries Journal, 29(12), 1687-1706.

Dafonte-Gómez, A. (2013). The key elements of viral advertising. from motivation to emotion in the most shared videos. Media Education Research Journal, 22 (43), 199-206.

Dellarocas, C. (2003). The digitization of word of mouth: Promise and challenges of online feedback mechanisms. Management Science, 49(10), 14071424.

Dick, A. S., \& Basu, K. (1994). Customer loyalty: toward an integrated conceptual framework. Journal of the academy of marketing science, 22(2), 99-113.

Godes, D., \& Mayzlin, D. (2004). Using online conversations to study word-of-mouth communication. Marketing Science, 23(4), 545-560.

Goldberg, M. E., \& Baumgartner, H. (2002). Cross-country attraction as a motivation for product consumption. Journal of Business Research, 55(11), 901-906.

Goyette, I., Ricard, L., Bergeron, J., \& Marticotte, F. (2010). e-WOM Scale: word-of-mouth measurement scale for e-services context. Canadian Journal of Administrative Sciences 27(1), 5-23.

Güven, E. (2014). Sosyal medyadaki ă̆ızdan ăğza pazarlama faaliyetlerinin satın alma kararlar üzerine etkileri, Doktora Tezi, Manisa: Celal Bayar Üniversitesi.

Hahn, M., Park, S., Krishnamurthi, L., \& Zoltners, A. A. (1994). Analysis of new product diffusion using a four-segment trial-repeat model. Marketing Science, 13(3), 224-247.

Heilman, C. M., Bowman, D., \& Wright, G. P. (2000). The evolution of brand preferences and choice behaviors of consumers new to a market. Journal of Marketing Research, 37(2), 139-155. 
Hennig-Thurau, T., Gwinner, K. P., Walsh, G., \& Gremler, D. D. (2004). Electronic word-of-mouth via consumer-opinion platforms: what motivates consumers to articulate themselves on the internet?. Journal of Interactive Marketing, 18(1), 38-52.

Hung, C. H. (2008). The effect of brand image on public relations perceptions and customer loyalty. International Journal of Management, 25(2), 237246.

Iacobucci, D., \& Hopkins, N. (1992). Modeling dyadic interactions and networks in marketing. Journal of Marketing Research, 29(1), 5-17.

Kahn, B., \& Wind, J. (2005). What's the buzz about buzz marketing. USA: Knowledge@Wharton.

Kalaycı, Ş. (2008). SPSS uygulamalı çok değişkenli istatistik teknikleri. Ankara: Asil Yayın Dağıtım.

Kardeş, İ. (2011). Markaların çevre dostu uygulamalarının tüketicinin marka tercihi üzerindeki etkisi. Ege Akademik Bakış Dergisi, 11(1), 165-177.

Kotler, P.H. \& Armstrong, G. (2006). Principles of marketing. New Jersey: Prentice-Hall.

Lim, K., \& O’Cass, A. (2001). Consumer brand classifications: an assessment of culture-of-origin versus country-of-origin. Journal of Product \& Brand Management, 10(2), 120-136.

Litvin, S. W., Goldsmith, R. E., \& Pan, B. (2008). Electronic word-of-mouth in hospitality and tourism management. Tourism management, 29(3), 458-468.

Loudon, D. L., \& Della Bitta, A. J. (1993). Consumer behavior: Concepts and applications. (4 th. Edition), New York: McGraw-Hill Companies.

Marangoz, M. (2007). Ağızdan ağıza iletişimin müşterilerin satın alma davranışlarına etkileri: Cep telefonu pazarına yönelik bir araştırma. Çukurova Üniversitesi Sosyal Bilimler Enstitüsü Dergisi, 16(2), 395-412.

Mohr, I. (2007). Buzz marketing for movies. Business Horizons, 50(5), 395-403.

Murray, K. B. (1991). A test of services marketing theory: consumer information acquisition activities. Journal of Marketing, 55(1), 10-25.

Nan, X. (2009). The influence of source credibility on attitude certainty: Exploring the moderating effects of timing of source identification and individual need for cognition. Psychology \& Marketing, 26(4), 321-332.

Overby, J. W., Gardial, S. F., \& Woodruff, R. B. (2004). French versus American consumers' attachment of value to a product in a common consumption context: a cross-national comparison. Journal of the Academy of Marketing Science, 32(4), 437-460.

Pickett-Baker, J., \& Ozaki, R. (2008). Pro-environmental products: marketing influence on consumer purchase decision. Journal of Consumer Marketing, 25(5), 281-293.
Piron, F. (2000). Consumers' perceptions of the country-oforigin effect on purchasing intentions of (in) conspicuous products. Journal of Consumer Marketing, 17(4), 308-321.

Punj, G. N., \& Hillyer, C. L. (2004). A cognitive model of customer-based brand equity for frequently purchased products: Conceptual framework and empirical results. Journal of Consumer Psychology, 14(1-2), 124-131.

Richins, M. L. (1983). Negative word-of-mouth by dissatisfied consumers: A pilot study. Journal of Marketing, 47(1), 68-78.

Sekaran, U. (1992). Research Methods of Business. Canada: Jonh Wiley \& Sons.

Silverman, G. (2007). Ağızdan ă̆ıza pazarlama: dünyanın en güçlü pazarlama yönteminin 28 sırrı (Çev. Ender Orfanl1). İstanbul: MediaCat Kitapları.

Sim, Ş. \& Toprak, M. (2012). Sinemayı hayata yaklaştırmak: Sahte Belgesel (Mockumentary) Fine Arts, 7 (1), 110.

Thomas Jr, G. M. (2004). Building the buzz in the hive mind. Journal of Consumer Behaviour: An International Research Review, 4(1), 64-72.

Thorson, K. S., \& Rodgers, S. (2006). Relationships between blogs as eWOM and interactivity, perceived interactivity and parasocial interaction. Journal of Interactive Advertising, 6(2), 5-44.

Torlak, Ö. \& Özmen, M. (2006). İki farklı kola markası tercih eden üniversite öğrencilerini ayıran özelliklerin belirlenmesine yönelik bir araştırma. Atatürk Üniversitesi İktisadi ve İdari Bilimler Dergisi, 20(2), 359-371.

Trusov, M., Bucklin, R. E., \& Pauwels, K. (2009). Effects of word-of-mouth versus traditional marketing: findings from an internet social networking site. Journal of Marketing, 73(5), 90-102.

Varinli, İ., \& Babayiğit, S. (2000). Tüketicilerin Türk ve Yabancı Orijinli Hazır Giyim Ürünlerine Yönelik Karşılaştırmalı Imaj Çalışması. 5.Ulusal Pazarlama Kongresi Bildiri Kitabi. Antalya.

Yıldız, E. (2015a). Marka bilinirliği ve algılanan kalitenin marka tercihi, müşteri tatmini ve ă̆ızdan ă̆ıza pazarlamaya etkileri. 14. Ulusal İşletmecilik Kongresi Bildiri Kitabı, Aksaray: Aksaray Üniversitesi.

Yıldız, E. (2015b). A Ăızdan ăgıza pazarlamanın marka tercihlerine etkisinde marka imajı ve alglanan kalitenin aracılık rolü: üniversite mezunları üzerine bir araştırma. 20. Ulusal Pazarlama Kongresi Bildiri Kitabı, Eskişehir: Anadolu Üniversitesi.

Yıldı, E.(2014). Tüketici temelli marka değeri ile ă̆ıdan ağıza pazarlama arasındaki ilişkide marka tercihinin aracılık rolü, Doktora Tezi, İstanbul: Haliç Üniversitesi. 